\title{
KARA DOCZESNA W PERSPEKTYWIE BOŻEGO MIŁOSIERDZIA
}

\section{WSTĘP}

Jednym z największych nieporozumień, jakie narosły wokół teologicznej refleksji nad miłosierdziem Bożym, jest przeciwstawianie sobie dwóch rzeczywistości: kary za grzech z jednej strony i miłości Bożej, której szczególnym przejawem jest miłosierdzie, z drugiej. Wydaje się, że jest to jeden z największych paradoksów współczesnego chrześcijaństwa. Katoliccy kaznodzieje i teologowie wiele miejsca w swoim nauczaniu i poszukiwaniach poświęcają refleksji nad dobrocią Boga. W Roku Miłosierdzia zostało otwartych wiele „bram miłosierdzia”, a wierni są zachęcani do zyskiwania odpustów zupełnych, których znaczenia jednak często się nawet nie wyjaśnia. Tymczasem, jeśli zyskujemy odpusty, to znaczy, że najpierw coś nam trzeba odpuścić... Coś tak poważnego, jak karę za grzechy. Wspomniany paradoks polega na tym, że o ile teologia protestancka odrzuciła dogmat o czyśćcu i odpustach, choć jednak w nauczaniu pastorów nie brakuje podejmowania trudnego tematu kary za grzechy, o tyle katolicy rozwijają refleksję o czyśćcu i o zyskiwaniu odpustów, ale o karze za grzechy mało kto już mówi¹. Wydaje się zatem całkiem

1 Taki stan rzeczy może wynikać z ujmowania problemu kary tylko i wyłącznie w perspektywie ostatecznej konsekwencji grzechu człowieka. Wówczas przez karę rozumie się tylko karę wieczną i ostateczne potępienie człowieka, który na nią 
uzasadnione pytanie, czy nauczanie o miłosierdziu bez podejmowania ważnego pytania o karę za grzechy, jest jeszcze zwiastowaniem całej Ewangelii i całego Chrystusa? Odpowiedź nasuwa się sama i wydaje się oczywista, ale prowokuje do postawienia kolejnego pytania: Czy miłosierdzie Boże pojawia się po to, by człowiek mógł uniknąć kary, czy też kara pojawia się dlatego, że Bóg okazuje człowiekowi swoje miłosierdzie?

\section{SPRAWIEDLIWOŚĆ BOGA A JEGO MILOSIERDZIE}

W całej historii zbawienia sprawiedliwość Boga jest rozumiana przede wszystkim jako Jego wierność - wierność przymierzu, wierność obietnicy, wierność danemu słowu². Bóg jest sprawiedliwy, ponieważ oddaje każdemu to, co się mu należy. W swojej strategii obdarowywania ludzi Bóg nie daje nikomu ani za dużo, ani za mało, ani tyle, ile ofiarował komuś innemu. On daje każdemu zapłatę według najwłaściwszej miary. Takie myślenie o sprawiedliwości często budzi w ludziach niepokój, ponieważ z relacji międzyosobowych, rodzinnych, społecznych zdążyli się nauczyć, że człowiek często oczekuje traktowania na równi z innymi. Wymownie ilustruje to przypowieść Jezusa o ludziach najmowanych do pracy o różnych

zasłużył i ją ponosi. W ten sposób zdaje się wypowiadać o karze papież Franciszek, Misericordiae vultus, bulla ustanawiająca nadzwyczajny Jubileusz Miłosierdzia, Rzym, 11 kwietnia 2015, w: http://www.opoka.org.pl/biblioteka/W/WP/franciszek_i/ bulle/misericordiae-lev_11042015.html (dostęp 30.06.2016), który łączy problem kary z dziełem zniszczenia i stwierdza, że w odniesieniu do Boga, „Jego bycie miłosiernym znajduje swe potwierdzenie w wielorakich dziełach historii zbawienia, gdzie dobroć Boga zwycięża nad chęcią kary i zniszczenia”.

${ }^{2}$ Na taki związek między ideą sprawiedliwości Boga i Jego wiernością wskazuje np. W. P o p i ele w s ki, Miłosierdzie a sprawiedliwość - pytanie o Boga w świetle ST, „Studia Pelplińskie”, (2004), t. 35, s. 41-42: „(...) miłosierdzie nie jest w żadnym stopniu czymś, co istnieje w Bogu obok sprawiedliwości. Jeśli tę ostatnią pojmujemy właściwie jako synonim lojalności, wierności, nachylenia nad człowiekiem, to miłosierdzie jawi się jako przejaw tak pojętej sprawiedliwości. Jest uruchomieniem mechanizmu uzdrawiania naruszonej przez partnera relacji”. 
porach dnia - ci, którzy pracowali cały dzień, spodziewali się zapłaty większej niż ta, którą dostali pracownicy ostatniej godziny. Kiedy jednak właściciel wypłacił im kwotę, na jaką pierwotnie się z nimi umówił, czuli się zawiedzeni, ponieważ uważali, że należy się im więcej. Taka roszczeniowa postawa popchnęła także jednego z rozmówców Jezusa do postulowania, by Mistrz wystąpił w roli arbitra w rodzinnym sporze o spadek. Jezus jednak uchyla się od podjęcia takiej misji. Doskonale wie, że kto kocha pieniądze, ten pieniądzem się nie nasyci (por. Koh 5, 9). Opowiadając jednak przypowieść o robotnikach pracujących w winnicy (zob. Mt 20, 1-16) wskazuje na ważną cechę sprawiedliwości Boga. Jak gospodarz wypłacił ustaloną $\mathrm{w}$ umowie sumę pieniędzy, tak Bóg daje człowiekowi zapłatę stosowną do warunków umowy, a nie według narastających pretensji człowieka. Bóg jest wierny swoim obietnicom i swojemu słowu (zob. Pwt 32, 4; Ne 9, 8; Ps 145, 13; 1 Kor 10, 13; 1 Tes 5, 23-24; 1 J 1, 8-9).

Zadziwiające jest jednak to, że jakkolwiek człowiekowi od Boga nic się nie należy, ponieważ wszystko w życiu człowieka jest niezasłużonym darem, to jednak Bóg zechciał, aby należała się człowiekowi Jego miłość. I w tym upodobnił człowieka do siebie, co zauważa św. Paweł, nawołując, abyśmy nikomu nie byli nic dłużni, aby nikomu nic się nie należało $\mathrm{z}$ naszej strony, poza... wzajemną miłością (zob. Rz 13, 8).

Sprawiedliwość Boga, Jego wierność danemu słowu, widać już w samych przymierzach, które Bóg zawiera z ludźmi. Kiedy On zawiera pakt z patriarchą Jakubem, składa mu obietnicę: ,Ja jestem z tobą i będę cię strzegł, gdziekolwiek się udasz (...). Bo nie opuszczę cię, dopóki nie spełnię tego, co ci obiecuję" (Rdz 28, 15). Bóg okazał się wręcz dramatycznie wierny tej obietnicy i pozostał obrońcą człowieka! Zechciał obronić grzesznika i w swoim Synu przelał za niego nawet swoją krew. Dzięki Bożej sprawiedliwości, czyli wierności złożonym obietnicom, ludzie są zaproszeni przez Boga do wejścia z Nim w relację na mocy szczególnego przymierza, które zostało przypieczętowane krwią Zbawiciela. Znakiem i zapowiedzią tego przymierza było m.in. przymierze, jakie Bóg zawarł z Abramem i jego potomstwem. 
Bóg wchodzi we wrażliwość człowieka i posługuje się znanymi człowiekowi obrzędami, aby dopełnić przymierza w sprawiedliwy sposób: „(...) kiedy słońce zaszło i nastał mrok nieprzenikniony, ukazał się dym jakby wydobywający się z pieca i ogień niby pochodnia i przesunęły się między tymi połowami zwierząt. Wtedy to właśnie Pan zawarł przymierze z Abramem (...)" (Rdz 15, 17-18a). Krew zwierząt jest zapowiedzią Krwi Chrystusa, a ogień przywołuje późniejszą manifestację Ducha Świętego (por. Dz 2, 3). Bóg w swojej wierności, w swojej sprawiedliwości, wprowadza w końcu człowieka nie tylko między części przepołowionych zwierząt, ale wprowadza go w otwarte serce swojego ukochanego Syna. W tej perspektywie można zrozumieć, że sprawiedliwość Boga to z jednej strony Jego wierność, a z drugiej - Jego zbawcza obecność. Jego obecność jest zawsze ocalająca, to znaczy, zawsze ratuje człowieka. Bóg wie, z czego stworzył ludzi, On pamięta, że człowiek jest prochem (por. Ps 103, 14), a jednak zaprasza go do przymierza ze sobą. Ponieważ jednak partnerzy tego przymierza nie są jednakowo mocni i ponieważ Bóg zna kondycję swojego kontrahenta, daje mu również zapewnienie swojej zbawiającej, ocalającej obecności przy nim³ ${ }^{3}$. Przy słabości człowieka będzie odtąd na zawsze stał Ten, który jest mocny. Bóg jest sprawiedliwy i wierny, dlatego zapowiedź miłosierdzia staje się zasadniczym elementem umowy między Nim i człowiekiem. W bardzo obrazowy sposób ten rys sprawiedliwości Boga, który

3 Jak słusznie zauważył J. Ratzinger: ,realna relacja Boga z człowiekiem, która jest istotna dla Starego Testamentu, wyrażana jest nie słowem komunia, lecz słowem «przymierze» (berith). Terminologia ta wskazuje, na wzniosłość Boga - tylko On może ustanowić relację ze stworzeniem. W ten sposób podkreślony jest zarazem dystans, którego relacja nie znosi. Na tej podstawie niektórzy egzegeci uważają nawet, że tłumaczenie berith jako «przymierza» jest niewłaściwe, gdyż słowo to zakłada pewną równość pomiędzy «partnerami» przymierza, a w starotestamentowej wizji relacji Bóg-człowiek równość taka nie może istnieć”. J. R a t z i n g e r, Patrzeć na Przebitego. Szkice o chrystologii duchowej, Kraków 2008, s. 77. Ideę starotestamentalnego przymierza jako „komunii” można z kolei znaleźć np. w publikacji G. G i a v i n i e g o, Ku Biblii... wstuchując się w jej przesłanie, Częstochowa 1999, s. 93. 
nazywamy miłosierdziem, został ukazany w Księdze Jonasza. W niej bowiem na opisanie Bożego miłosierdzia zostało użyte wyrażenie rahum (םוּחר, które pochodzi od פחרז, oznaczającego łono kobiety, miejsce, w którym powstaje nowe życie $)^{4}$. Kiedy Jonasz znalazł się na dnie morza, doświadczył niezwykłej interwencji Boga, który czekał na niego właśnie tam, w ciemnościach morskiej głębiny. Bóg posyła ogromną rybę, aby stała się schronieniem dla proroka. Kiedy Jonasz został otulony wnętrznościami ryby, otuliło go miłosierdzie Boga, które on nazwie potem rahum (zob. Jon 4, 2). Bardzo wyraźnie uwidacznia się w tym kontekście istota miłosierdzia, do której należy pragnienie Boga, by ocalić człowieka. Bóg jest sprawiedliwy, dlatego dochowuje swojej części przymierza i dlatego chroni i czuwa nad ludzkim życiem. Miłosierdzie Boga jest wpisane w Jego sprawiedliwość ${ }^{5}$. Czas miłosierdzia oznacza $w$ istocie czas dany człowiekowi na nawrócenie. Podkreślał to w swoich rozważaniach bł. ks. Michał Sopoćko, który pisał wprost, że ,przed straszną karą potopu czas miłosierdzia ciągnął się przez sto lat, a dla Niniwitów trwał tylko dni czterdzieści. (...) Każdemu z nas wyznaczona jest chwila miłosierdzia i pokuty za grzechy: biada duszy, która jest niebaczna na ten czas miłosierdzia"

Ponieważ celem miłosierdzia jest ratowanie życia człowieka w perspektywie powołania do nieśmiertelności, do wieczności, Bóg

${ }^{4}$ Zob. http://biblehub.com/hebrew/7349.htm i http://biblehub.com/hebrew/7358. htm (dostęp 27.06.2016).

5 J a n Paweł II, Encyklika «Dives in misericordia», 4, w: Encykliki Ojca Świętego Jana Pawła II, tom 1, Kraków 1996, s. 68-69, stwierdził, że „miłość niejako warunkuje sprawiedliwość, a sprawiedliwość ostatecznie służy miłości. Ów prymat, pierwszeństwo miłości w stosunku do sprawiedliwości (co jest rysem znamiennym całego Objawienia), ujawnia się właśnie poprzez miłosierdzie. Było to do tego stopnia oczywiste dla Psalmistów i Proroków, że sam termin sprawiedliwość oznacza u nich zbawienie dokonane przez Boga i Jego miłosierdzie (por. Ps 40 [39], 11; 98 [97], 2n.; Iz 45, 21; 51, 5. 8; 56, 1)”.

${ }_{6}$ M. S o p o ć k o, Miłosierdzie Boże. Studjum teologiczno-praktyczne, Wilno 1936, s. 19. Zob. także: S. W i śn i e w s k i, Błogosławiony ks. Michał Sopoćko. Kapłan o miłosiernym obliczu, w: „Łódzkie Studia Teologiczne”, 24(2015) nr 4, s. 115. 
posługuje się środkami wychowawczymi, które mają pomóc człowiekowi wytrwać na drodze do życia wiecznego. Oznacza to, że Bóg posługuje się także karą doczesną, która nie jest jednak w żaden sposób działaniem krzywdzącym człowieka, lecz narzędziem uzdrawiającym go i pomagającym mu wywiązać się ze swojej części umowy przymierza. Zatem Bóg, który jest wierny i sprawiedliwy, dąży do tego, by jego partner w przymierzu również okazał się sprawiedliwy i wierny, dlatego okazuje mu miłosierdzie, które czasem przychodzi w formie gorzkiego lekarstwa, które człowiek może rozumieć jako karę doczesną. Tu jednak nasuwa się pytanie, czy można w ogóle dopuścić myśl o karze, skoro przyjmuje się orędzie o Bożym miłosierdziu?

\section{MIŁOSIERDZIE BOGA A PROBLEM KARY}

Słowo Boże wiele razy mówi o łaskawości i miłosierdziu Boga. Stary Testament obfituje w piękne obrazy, które mają pobudzić do gorliwego wychwalania dobroci Stwórcy. Warto wspomnieć w tym kontekście chociażby kantyk trzech młodzieńców z Dn 3, 51-89, czy też pełną zachwytu nad wspaniałością Boga modlitwę z Księgi Nehemiasza (9, 7-21), w której autor natchniony wspomina dzieje Abrahama, z którym Bóg zawarł przymierze i dotrzymał słowa, ponieważ jest wierny. $W$ dalszych słowach opowiedziana jest historia miłosierdzia Bożego objawionego w wyprowadzeniu Hebrajczyków z niewoli egipskiej i w nadaniu im Prawa na Synaju. W końcu padają słowa wychwalające wprost miłosierdzie Boga: „Lecz oni, ojcowie nasi, postępowali zuchwale, byli krnąbrni i nie słuchali Twoich przykazań. I uchylali się od posłuszeństwa i nie pamiętali o cudach, któreś dla nich uczynił. (...) Lecz Ty jesteś Bogiem przebaczenia, jesteś łaskawy i miłosierny, cierpliwy i wielkiej dobroci; i nie opuściłeś ich. (...) Ty w wielkim miłosierdziu twoim nie opuściłeś ich na pustyni. (...) Przez czterdzieści lat zaopatrywałeś ich na pustyni, tak że nie odczuwali braku. Szaty ich się nie zniszczyły, a nogi ich nie spuchły" (Ne 9, 16-21). W każdym zdaniu tej modlitwy ujawnia się wielki zachwyt człowieka nad miłosierdziem Boga. 
Bóg, który zna słabość człowieka i wie o jego skłonności do grzechu, nie przestaje go jednak kochać. W niezwykle czułych słowach wypowiada tę prawdę przez usta Ozeasza: „Miłowałem Izraela, gdy jeszcze był dzieckiem, i syna swego wezwałem z Egiptu. Im bardziej ich wzywałem, tym dalej odchodzili ode Mnie, a składali ofiary Baalom i bożkom palili kadzidła. A przecież Ja uczyłem chodzić Efraima, na swe ramiona ich brałem; oni zaś nie rozumieli, że troszczyłem się o nich. Pociągnąłem ich ludzkimi więzami, a były to więzy miłości. Byłem dla nich jak ten, co podnosi do swego policzka niemowlę - schyliłem się ku niemu i nakarmiłem go" (Oz 11, 1-4). Emocjonalne napięcie tej wypowiedzi zdaje się rosnąć wraz z kolejnym zwierzeniem Boga, który ze smutkiem zauważa: „Mój lud jest skłonny odpaść ode Mnie - wzywa imienia Baala, lecz on im nie przyjdzie z pomocą. Jakże cię mogę porzucić, Efraimie, i jak opuścić ciebie, Izraelu? (...) Moje serce na to się wzdryga i rozpalają się moje wnętrzności. Nie chcę, aby wybuchnął płomień mego gniewu i Efraima już więcej nie zniszczę, albowiem Bogiem jestem, nie człowiekiem; pośrodku ciebie jestem Ja - Święty, i nie przychodzę, żeby zatracać" (Oz 11, 7-9). Boże miłosierdzie po raz kolejny jest tu porównane do wnętrzności, które rozpalają się, na myśl o dziecku, które się oddala, które naraża się na największe nieszczęście. Można zatem zauważyć, że miłosierdzie Boga zostaje niejako wywołane, rozbudzone czy rozpalone na skutek oglądania niewierności, czyli egzystencjalnej porażki człowieka, który popada w nędzę duchową. Najważniejsza jednak jest konkluzja tego monologu, w której Bóg zapewnia, że nie przychodzi po to, aby zatracać, ale po to, aby uratować człowieka, czyli przywrócić mu zdolność do wywiązania się z warunków przymierza. Ostatecznym pragnieniem Boga jest zbawienie człowieka (zob. $1 \mathrm{Tm} 2,4)$. $\mathrm{Z}$ tego powodu nie oszczędził On nawet własnego Syna (zob. Rz 8, 32) i zrzucił na Niego winę wszystkich (zob. Iz 53,6), aby otworzyć przed ludźmi perspektywę życia wiecznego i uwolnienia od kary wiecznej (zob. J 3, 16). Nie zawsze jednak człowiek przyjmuje tę hojność Boga i wprowadza siebie w sytuację nędzy, która znów woła o miłosierdzie Boże. I Bóg nie zamyka swoich uszu na wołanie człowieka (zob. Ps 34, 7), ale 
przychodzi z ocalającym miłosierdziem, które czasem posługuje się także karą doczesną, aby uchronić ludzkie życie przed karą wieczną.

Chcąc omówić problem kary za grzech, należy uwzględnić, że sam grzech jest już karą, czy też - mówiąc precyzyjniej - kara jest zawarta już w samym grzechu? Katechizm Kościoła Katolickiego wyjaśnia w tym kontekście, że „każdy grzech, nawet powszedni, powoduje ponadto nieuporządkowane przywiązanie do stworzeń, które wymaga oczyszczenia, albo na ziemi, albo po śmierci, w stanie nazywanym czyśćcem. Takie oczyszczenie uwalnia od tego, co nazywamy «karą doczesną» za grzech. Obydwie kary nie mogą być traktowane jako rodzaj zemsty, którą Bóg stosuje od zewnątrz, ponieważ wypływają one jakby z samej natury grzechu. Nawrócenie, które pochodzi z żarliwej miłości, może doprowadzić do całkowitego oczyszczenia grzesznika, tak że nie pozostaje już żadna kara do odpokutowania" (KKK 1472). Na szczególną uwagę zasługuje stwierdzenie mówiące o tym, że kara nie przychodzi z zewnątrz i nie służy jako narzędzie odwetu w ręku rozgniewanego Boga. Jest to o tyle ważne, że brak zrozumienia celowości kary staje się najczęstszym powodem przeciwstawiania jej idei miłosierdzia Bożego. Zbyt łatwe przekładanie egzystencjalnych doświadczeń człowieka na wyobrażenia o motywach działania Boga, staje się zbyt często źródłem niebezpiecznego psychologizowania i dokonywania szkodliwych projekcji osobistych, subiektywnych traum na relację ze Stwórcą.

Kolejną trudność stanowić może jedna z najstarszych zasad określających funkcjonowanie kar w życiu społecznym, którą jest tzw. prawo talionu (ius talionis), nakazujące wymierzyć karę dokładnie odpowiadającą swoim ciężarem przewinieniu: oko za oko i ząb za ząb.

7 J. S a li j, Zło. Cierpienie. Nadzieja, Poznań-Kraków 2001, s. 67, zauważa, że „ "Grzech sam w sobie jest karą» - powiada mądre przysłowie. To prawda, że czasem działa on jak narkotyk i może dać człowiekowi na jakiś czas poczucie szczęścia i spełnienia, ale obiektywnie każdy grzech zmienia sytuację człowieka na gorsze. Toteż najbardziej tragiczną i przeklętą karą za grzech jest to, że otwiera on wrota do grzechów następnych. Jak powiada Apostoł Paweł: Tych, którzy nie liczą się z Bogiem, «wydał Bóg na pastwę ich bezużytecznego rozumu, tak że czynią to, co się nie godzi» (Rz 1, 28)”. 
Człowiek boi się nawet myśleć, jak surowe konsekwencje mogłyby mu grozić za nieposłuszeństwo Bogu, skoro zacząłby On - niejako wbrew miłosierdziu - traktować człowieka według tej zasady. $\mathrm{Na}$ szczęście dla człowieka te obawy - jakkolwiek nieprzyjemne - pozostają jedynie w sferze wyobraźni. Kara doczesna, która nie tkwi w samej naturze grzechu, ale - jako jego konsekwencja - stanowi trudną do zaakceptowania uciążliwość w życiu człowieka, jest bowiem zawsze narzędziem działania Bożego miłosierdzia. Nasuwa się jednak pytanie o celowość kary doczesnej.

\section{CELOWOŚĆ KAR DOCZESNYCH}

Uważna lektura słowa Bożego pozwala wyodrębnić trzy teleologiczne wymiary (rodzaje) kary doczesnej za grzechy. Ze względu na celowość można mówić o karach: prewencyjnej (cel dydaktyczny), terapeutycznej (cel uzdrawiający) i pedagogicznej (cel wychowawczy). Kara prewencyjna ma na celu odstraszyć człowieka od popełnienia grzechu i wzbudzić w nim ten szczególny rodzaj strachu, którym jest bojaźń Boża. O ile strach przed nieuniknioną koniecznością poniesienia osobistych konsekwencji już popełnionego zła jest naturalnym odruchem człowieka i jako taki jest wspomniany na kartach Biblii już w Księdze Rodzaju ${ }^{8}$, o tyle bojaźń Boża jest tym rodzajem błogosławionego lęku, którego człowiek po grzechu pierworodnym musi się uczyć. Katechizm Kościoła Katolickiego stwierdza, że „bojaźń przed złem wywołuje nienawiść, wstręt i lęk przed złem przyszłym. Bojaźń ta kończy się smutkiem z powodu istniejącego zła lub gniewem, który się mu sprzeciwia” (KKK 1765). Dlatego jest ona „początkiem mądrości” (Syr 1, 14), ,podstawą wiedzy” (Prz 1, 7) i „szkołą mądrości”

${ }^{8}$ Po popełnieniu grzechu nieposłuszeństwa Adam ukrywa się przed Bogiem, ponieważ czuje strach: „Pan Bóg zawołał na mężczyznę i zapytał go: «Gdzie jesteś?». On odpowiedział: «Usłyszałem Twój głos w ogrodzie, przestraszyłem się, bo jestem nagi, i ukryłem się»” (Rdz 3, 9-10). O tym rodzaju lęku, który kojarzy się z karą, mówi także Nowy Testament: „W miłości nie ma lęku, lecz doskonała miłość usuwa lęk, ponieważ lęk kojarzy się z karą. Ten zaś, kto się lęka, nie wydoskonalił się w miłości $(1 \mathrm{~J} 4,18)$. 
(Prz 15, 33). Specyficzną drogą przyjmowania przez człowieka daru bojaźni Bożej jest według proroka Jeremiasza doświadczanie trudnych sytuacji. Prorok wyraża swoje przekonanie modlitwą: „Panie! Czyż oczy Twoje nie są zwrócone ku temu, co prawdziwe? Dotknąłeś ich klęską - nic sobie z tego nie robili, zagładą - nie chcieli przyjąć pouczenia. Skamieniało ich oblicze bardziej niż skała, i nie nawrócili się" (Jr 5, 3). W tej samej księdze Bóg wypowiada pełne smutku słowa: „Dlaczego się ze Mną sprzeczacie? Wszyscy zgrzeszyliście przeciw Mnie - wyrocznia Pana. Na próżno karałem synów waszych: nie przyjęli tego jako nauki” (Jr 2, 29-30a). Z tej wypowiedzi można wyprowadzić wniosek, że Bóg posługuje się karą, ponieważ chce nauczyć człowieka mądrości, czyli chce jego dobra, jego ocalenia9 Stąd wyłania się wprost motywacja działania Boga, a jest nią Jego miłosierdzie.

Drugi wymiar kary doczesnej ukazuje jej znaczenie terapeutyczne. Jest ona narzędziem dzięki któremu człowiek może zostać uzdrowiony, czyli ocalony ze swojej niemocy wywiązania się z warunków przymierza z Bogiem. W Księdze Apokalipsy zostały zapisane słowa modlitwy męczenników, którzy wołają do Boga: „Dokądże, Władco święty i prawdziwy, nie będziesz sądził i wymierzał za krew naszą kary tym, co mieszkają na ziemi?" (Ap 6, 10). Zbawieni, ci, którzy ją otrzymali nagrodę za swoje trudy, proszą Boga o karę dla tych, którzy ich prześladowali na ziemi. Trudno posądzać zbawionych

9 Bardzo sugestywną opowieść, ukazującą zależność istniejącą między miłosierdziem i karą w jej wymiarach prewencyjnym i terapeutycznym, można znaleźć w antologii stworzonej przez D. L i f s c h it z a, Z madrości chasydów, Kielce 2003, s. 38: „Rabbi z Międzyrzecza tak nauczał: «Pewien ojciec podniósł swego synka, który się przewrócił i zauważywszy drzazgę w stopie dziecka, wyciągnął ją, nie zważając na krzyki małego. A potem powiedział: 'Jeżeli nie będziesz bardziej uważał podczas zabawy, znów będziesz cierpiał tak, jak przed chwilą. Bali się i ojciec, i syn: ojciec - zakażenia nogi synka; chłopiec - bólu. Podobnie Bóg zsyła nam karę, żeby nas uzdrowić od grzechu. On boi się tego, co jest złe dla naszej duszy, a my boimy się kary, która jest dla niej uzdrowieniem. Nie zachowujmy się dłużej jak dzieci i zastanówmy się, co naprawdę powinno wzbudzać naszą obawę»”". 
o pragnienie zemsty. Jeśli proszą o karę, to znaczy, że wiedzą o jej leczącym wpływie na życie człowieka, któremu grozi wieczne potępienie $^{10}$.

Na terapeutyczny cel kary wskazuje także skarga Boga zapisana w Psalmie 50, 16-22: „A do grzesznika Bóg mówi: «Czemu wyliczasz moje przykazania i masz na ustach moje przymierze ty, co nienawidzisz karności i moje słowa rzuciłeś za siebie? Ty widząc złodzieja, razem z nim biegniesz i trzymasz z cudzołożnikami. W złym celu otwierasz usta, a język twój knuje podstępy. Zasiadłszy, przemawiasz przeciw swemu bratu, znieważasz syna swojej matki. Ty to czynisz, a Ja mam milczeć? Czy myślisz, że jestem podobny do ciebie? Skarcę ciebie i postawię ci to przed oczy. Zrozumcie to wy, co zapominacie o Bogu, bym nie porwał, a nie byłoby komu zbawić". Po wyliczeniu grzechów, Bóg przypomina o tym, że Jego celem jest zbawienie człowieka, które niestety jest zagrożone świadomym odrzuceniem przymierza. Bóg zapowiada zatem, że Jego sposobem ratowania nieszczęśnika będzie zesłanie na niego kary. „Skarcę ciebie” (Ps 50, 21) jest zatem obietnicą ocalenia. Bóg karci nie po to, by zemścić się na niewiernym słudze, ale po to, aby człowiek mógł przejrzeć na oczy, zobaczyć swój grzech, uznać go i wrócić na drogę sprawiedliwości. To przekonanie towarzyszy także Kościołowi, kiedy prosi Boga o miłosierdzie, które przychodzi poprzez pokutę, i woła w liturgii godzin: „Grzechy moje utkwiły we mnie jak strzały, uzdrów mnie, Boże, lekarstwem pokuty"ll. Pokuta bowiem, której przeżywanie ma dla człowieka wymiar kary doczesnej, staje się drogą oczyszczenia i remedium na popełnione $\mathrm{zło}^{12}$.

${ }^{10}$ J. S a li j, Zło..., dz. cyt., s. 69, słusznie zauważa, że ,jest to modlitwa męczenników, którzy już oglądają święte oblicze Boga. Czyż serce nie podpowiada nam, że oni błagają Boga, aby nie zrażał się zatwardziałością swoich nieprzyjaciół, ale miłosiernie spuścił na nich utrapienia? Przecież nawet skałę da się skruszyć!”.

${ }^{11}$ Liturgia godzin. Codzienna modlitwa ludu Bożego, tom II, Poznań 1984, s. 187.

12 Jak słusznie zauważają L. S of i e ld, C. J u l i a n o, G.M. Ay m o nd, Facing forgiveness. A Catholic's Guide to Letting Go of Anger and Welcoming Reconciliation, Notre Dame (IN) 2007, s. 114: ,the penance can be seen somewhat 
Bóg sięga po karę, która jest środkiem leczniczym, aby człowiek powrócił do wierności przymierzu ze swoim Stwórcą. Dzieje narodu wybranego ukazują bezsprzeczną troskę Boga i Jego wielkie miłosierdzie, które czasem przychodzi poprzez trudne wydarzenia. Księga Sędziów opisuje na przykład ucisk, jaki przeżywali Izraelici, kiedy odchodzili od Boga. Ich niewierność została ukarana. Jednak celem kary nie było wyniszczenie narodu, ale doprowadzenie go do właściwej relacji z Bogiem. Kiedy przyszedł ucisk, naród, który grzeszył, znów powrócił do Boga: „Izraelici [znów] czynili to, co złe w oczach Pana, i Pan wydał ich na siedem lat w ręce Madianitów. (...) Zdarzało się, że ledwie Izraelici co zasiali, przychodzili Madianici i Amalekici oraz lud ze wschodu słońca i napadali na nich, a rozbijając obozy naprzeciwko nich, niszczyli plony ziemi aż ku granicom Gazy. Nie pozostawiali Izraelowi żadnych środków do życia - ani owiec, ani wołów, ani osłów. (...) Madianici wtrącili więc Izraela w wielką nędzę. Poczęli zatem Izraelici wołać do Pana" (Sdz 6, 1-6). Warto zauważyć, że kara, jaką Bóg sprowadza na Izraelitów ma precyzyjnie określony czas trwania. Siedem lat, to czas określający pełnię. Bóg pozwala człowiekowi doświadczyć kary w takim wymiarze, jaki jest niezbędny do jego uzdrowienia. On nigdy nie zsyła kary zbyt małej, ani zbyt wielkiej, ponieważ kara nie jest celem samym w sobie, ale środkiem prowadzącym do ocalenia. Lekarstwo zawarte w karze doczesnej musi być więc zaaplikowane w odpowiedniej dawce, aby spełniło swoje zadanie. Kiedy zatem wypełnił się czas kary, a naród zaczął wracać do duchowego zdrowia i znów wołał do Boga, Ten powołał Gedeona, aby przez niego ocalić swój lud (zob. Sdz 6, 11-7, 15).

Bóg wprowadza człowieka w doświadczenie ucisku lub wprost wyprowadza go na pustynię, gdzie brzmią tylko dzikie głosy (por. Pwt 32,10), po to, aby uwrażliwić jego serce na swój głos (zob. Oz 2, 16). Kara, która wydaje się przykrym i bolesnym doświadczeniem, staje się zatem prawdziwym lekarstwem i terapeutycznym narzędziem w ręku Bożego miłosierdzia.

as a medicine, a remedy, or a therapy, not only to celebrate new life, but to show us a new way to live and to embrace in a deeper way God's love and healing power". 
Trzeci w końcu wymiar kary doczesnej, to wymiar pedagogiczny, ukazujący miłosierdzie Boga w Jego trosce o wychowanie człowieka do wierności przymierzu. Już w Księdze Przystów można znaleźć przekonanie, że „karci Pan, kogo miłuje, jak ojciec syna, którego lubi” (Prz 3, 12). Także Syrach stwierdza, że „kto miłuje swego syna, często używa na niego rózgi, aby na końcu mógł się nim cieszyć" (Syr 30, 1). O ile bowiem słowo Boże poucza człowieka (zob. Ps 119, 130), o tyle kary mają go wychować (zob. 2 Mch 6,12). Nawet wtedy, kiedy naród wybrany przeżywał niezwykle tragiczne wydarzenia, to jednak wiedział, że one mają ich wychowywać do wierności Bogu. Świadectwem takiego przekonania są wydarzenia opisane w Drugiej Księdze Machabejskiej, która opowiada o niezwykłym bohaterstwie Żydów, którzy byli prześladowani z powodu swojej wiary. Zbezczeszczono wówczas świątynię jerozolimską, zakazano zachowywania szabatu i świąt, a nawet zabroniono przyznawać się do tego, że jest się Żydem (zob. 2 Mch 6, 1-9).

Jakby było mało nieszczęść, zabroniono także Żydom obrzezywania swoich synów, czyli przekazywania im znaku przymierza z Jahwe. Ciągłość przymierza miała zostać zerwana. Wtedy jednak „,przed sąd przyprowadzono dwie kobiety, gdyż obrzezały swe dzieci. Zawiesiwszy im przy piersiach ich niemowlęta oprowadzono je publicznie po mieście, a następnie strącono z muru" $(2 \mathrm{Mch} 6,10)$. Tak wielkie nieszczęście mogłoby sprowokować pytanie „dlaczego?”. Autor natchniony kieruje jednak do czytelnika pełne pokory słowo wyjaśnienia: „Proszę więc tych, którzy będą czytali tę księgę, aby nie wpadli w przygnębienie z powodu tego, co trzeba było znieść; żeby raczej na to zwracali uwagę, że prześladowania były nie po to, aby zniszczyć, ale aby wychować nasz naród. Znakiem bowiem wielkiego dobrodziejstwa jest to, iż grzesznicy nie są pozostawieni w spokoju przez długi czas, ale że zaraz dosięga ich kara. Nie uważał bowiem Pan, że z nami trzeba postępować tak samo, jak z innymi narodami, co do których pozostaje cierpliwy i nie karze ich tak długo, aż wypełnią miarę grzechów. Nie chciał bowiem karać nas na końcu, dopiero wtedy, gdyby grzechy nasze przebrały miarę. A więc nigdy nie cofa On od nas swojego miłosierdzia; choć wychowuje przez 
prześladowania, to jednak nie opuszcza swojego ludu" (2 Mch 6, 1216) ${ }^{13}$. Autor natchniony stawia zatem niezwykle jasno kwestię kary i miłosierdzia, które wzajemnie się nie wykluczają, ale należą do tej samej pedagogii Boga, który nieustannie okazuje człowiekowi swoje miłosierdzie.

\section{PODSUMOWANIE}

Jedną z trudności nasuwających się przy szukaniu odpowiedzi na pytanie, jakie jest znaczenie kary doczesnej za grzechy, pozostaje bliski związek tego problemu z pytaniem o sens cierpienia w ogóle. Celem niniejszego artykułu nie było jednak szukanie odpowiedzi na pytanie o znaczenie cierpienia, ale na specyficzny jego zakres związany z karą doczesną za grzechy, w kontekście Bożej sprawiedliwości i miłosierdzia. Poszukiwania teologiczne pozwoliły wykazać, że jedną z odsłon miłosierdzia Bożego w życiu człowieka jest doczesna kara za grzechy. Wynika ona zarówno z Bożej sprawiedliwości, jak i z Bożego miłosierdzia. Ponieważ Bóg jest sprawiedliwy, jest także wierny swojej miłości do człowieka, zatem zawsze otwiera nowe perspektywy powrotu człowieka do wierności przymierzu. Sprawiedliwość zatem przejawia się w miłosierdziu, a miłosierdzie nie boi się posłużyć karą doczesną, byle by ocalić człowieka nie tylko na chwilę, ale na całą wiecznośćc ${ }^{14}$.

13 Podejmując refleksję nad wydarzeniami opisanymi w Drugiej Księdze Machabejskiej, J. S a l i j, Zło..., dz. cyt., s. 68-69, zauważa, iż „sami wiemy najlepiej, że to trudne miłosierdzie Boga wobec nas - miłosierdzie wyrażające się spuszczeniem na nas utrapień - bywa szczególnie skuteczne. Iluż to ludzi pod wpływem doznanych utrapień opamiętało się!”.

${ }^{14}$ Kościół naucza, że „przebaczenie grzechu i przywrócenie komunii z Bogiem pociągają za sobą odpuszczenie wiecznej kary za grzech. Pozostają jednak kary doczesne. Chrześcijanin powinien starać się, znosząc cierpliwie cierpienia i różnego rodzaju próby, a w końcu godząc się spokojnie na śmierć, przyjmować jako łaskę doczesne kary za grzech. Powinien starać się przez dzieła miłosierdzia i miłości, a także przez modlitwę i różne praktyki pokutne uwolnić się całkowicie od «starego człowieka» i «przyoblec człowieka nowego»” (KKK 1473). 
Bóg jest dobry. Jest sprawiedliwy i miłosierny. Sprowadza sprawiedliwą karę doczesną, ale nie ma ona charakteru niszczącego człowieka, tylko zadanie przestrzeżenia człowieka przed śmiercią grzechu (zob. Rz 6, 23) lub sprowadzenia go z powrotem na droge wierności przymierzu z Bogiem przez nawrócenie (zob. Ez 18, 32), lub też wychowanie go do życia zgodnego $\mathrm{z}$ warunkami przymierza (Ap 3, 19). Miłosierdzie Boże nie sprzeciwia się w żaden sposób Bożej sprawiedliwości i nie oznacza, że Bóg rezygnuje z karcenia tych, których kocha. Przeciwnie - kara pojawia się właśnie dlatego, że Bóg okazuje człowiekowi swoje miłosierdzie.

\section{Temporal Punishment in the View of God's Mercy Summary}

The Jubilee Year of Mercy is a great opportunity to undertake deep reflection on the God's Mercy. One of the most important issues is the question about connection between God's Mercy and necessity of temporal punishment for sins. The question arises: Does God's Mercy occur after this, so that man could avoid punishment? The author, analyzing biblical texts and the Magisterium of the Church, proves that the temporal punishment for sins appear because God shows His Mercy to man. The Bible allows to discover three causes of the temporal punishment, which clearly indicates God's Mercy: the cause of prevention, therapeutic purpose and the pedagogical goal. God punishes man because of His Mercy. He wants man to be faithful in observing the Covenant Rights and so to achieve the life everlasting.

Slowa kluczowe: Miłosierdzie Boże, kara za grzechy, kara doczesna, kara wieczna, sprawiedliwość Boża, wierność Boga, przymierze Boga z ludźmi, celowość kary za grzechy, nawrócenie.

Key words: God's Mercy, a punishment for sin, temporal punishment, eternal punishment, the justice of God, the faithfulness of God, God's covenant with the people, necessity of punishment for sin, repentance.

Nota o autorze: Sebastian Wiśniewski OMI, doktor nauk teologicznych, wykładowca w Wyższym Seminarium Duchownym Misjonarzy Oblatów Maryi Niepokalanej w Obrze (Wydział Teologiczny Uniwersytetu im. Adama Mickiewicza w Poznaniu) oraz w Wyższym Seminarium Duchownym Towarzystwa Chrystusowego dla Polonii Zagranicznej w Poznaniu (Papieski Wydział Teologiczny w Warszawie). 


\section{Bibliografia:}

Franciszek, Misericordiae vultus, bulla ustanawiająca nadzwyczajny Jubileusz

Miłosierdzia, Rzym, 11 kwietnia 2015, w: http://www.opoka.org.pl/biblioteka/W/

WP/franciszek_i/bulle/misericordiae-lev_11042015.html.

Giavini G., Ku Biblii... wstuchując się w jej przestanie, Częstochowa 1999.

http://biblehub.com.

Jan Paweł II, Encyklika «Dives in misericordia», 4, w: Encykliki Ojca Świętego

Jana Pawła II, tom 1, Kraków 1996.

Katechizm Kościoła Katolickiego, Poznań 1994.

Lifschitz D., Z madrości chasydów, Kielce 2003.

Liturgia godzin. Codzienna modlitwa ludu Bożego, tom II, Poznań 1984.

Pismo Święte Starego i Nowego Testamentu. Biblia Tysiaclecia, Wydanie IV, Poznań 2003.

Popielewski W., Miłosierdzie a sprawiedliwość - pytanie o Boga w świetle ST, „Studia Pelplińskie”, (2004) t. 35, s. 41-42.

Ratzinger J., Patrzeć na Przebitego. Szkice o chrystologii duchowej, Kraków 2008.

Salij J., Zło. Cierpienie. Nadzieja, Poznań-Kraków 2001.

Sofield L., Juliano C., Aymond G.M., Facing forgiveness. A Catholic's Guide to Letting Go of Anger and Welcoming Reconciliation, Notre Dame (IN) 2007.

Sopoćko M., Miłosierdzie Boże. Studjum teologiczno-praktyczne, Wilno 1936.

Wiśniewski S., Błogosławiony ks. Michat Sopoćko. Kapłan o miłosiernym obliczu, w: „Łódzkie Studia Teologiczne”, 24(2015) nr 4, s. 111-121. 